Pteridines

Vol. 23, 2012, pp. $111-122$

\title{
Effect of N-acetyl cysteine, Neopterin and Dexamethasone on the Viability of Titanium dioxide Nanoparticles Exposed Cell Lines
}

\author{
Ayse Basak Engin ${ }^{1}$, Evren Doruk Engin ${ }^{2}$, Bensu Karahalil ${ }^{1}$ \\ ${ }^{1}$ Gazi University, Faculty of Pharmacy, Department of Toxicology, Hipodrom, Ankara, Turkey \\ ${ }^{2}$ Ankara University, Biotechnology Institute, Tandogan, Ankara, Turkey
}

Accepted: 2012/12/18

\begin{abstract}
Titanium is extensively used for a wide range of implanted medical devices due to its advantageous combination of physico-chemical and biological properties. Nano-size titanium dioxide $\left(\mathrm{TiO}_{2}\right)$ is also used in a variety of consumer products. Such widespread use and its potential entry through various routes of the body suggest that $\mathrm{TiO}_{2}$ could pose an exposure risk to humans. Nano-size particles (NP) enter systemic circulation, accumulate and damage tissues that are especially sensitive to oxidative stress. We hypothesized that $\mathrm{TiO}_{2} \mathrm{NPs}$ can exert diverse cytotoxic effects on various human cell type especially neural cell lines. In order to test our hypothesis, putative cytotoxic effects of oxidative stress due to $\mathrm{TiO}_{2}$ NPs exposure on IM9, U937 and SHSY5Y (human neuroblastoma cells) were investigated in $\mathrm{N}$-acetyl cysteine (NAC), neopterin and dexamethasone pre-treated cell cultures. IM9, U937 and SHSY5Y cells were exposed to ten different concentrations of 25 and $10 \mathrm{~nm}$ diameter $\mathrm{TiO}_{2} \mathrm{NPs}_{\text {in }}$ three different time periods before and after treatment with NAC, neopterin and dexamethasone. To determine toxicity levels of NPs, cell viability was estimated by MTT test. Concentration of cells was assessed by counting trypan blue stained cells with a heamo-cytometer. Toxicity of $25 \mathrm{~nm} \mathrm{TiO}_{2}$ particles was significantly increased $(\mathrm{p}<0.05)$ by adding fetal bovine serum (FBS) in SHYS5Y and U937 cell lines culture medium. Concentrationdependent toxicity of $10 \mathrm{~nm} \mathrm{TiO} 2$ NP was weakly increased by adding FBS to SHYS5Y, IM9 and U937 cell culture media. NAC pre-treatment provided significant protection for only SHYS5Y cell exposed to $25 \mathrm{~nm}$ and 10 nm of $\mathrm{TiO}_{2}$ NPs after a 24-hour incubation period. Neopterin pre-treated SHYS5Y cells displayed significant

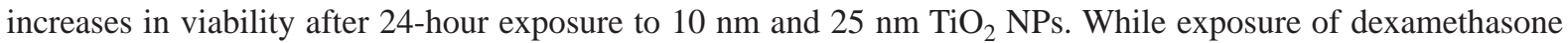
pre-treated U937 cells to $25 \mathrm{~nm}$ of $\mathrm{TiO}_{2} \mathrm{NPs}$ induced a significant increase in cell survival at only $100 \mu \mathrm{g} / \mathrm{ml} \mathrm{par}$ ticle concentration, increase in viability of SHYS5Y cells were observed at all concentrations against $10 \mathrm{~nm}$ particle challenge. Our study demonstrated that exposure of SHYS5Y to $\mathrm{TiO}_{2} \mathrm{NPs}_{\text {for }} 24$ hours regularly induced reduction of cell viability. We also found similar dose-related effects of $\mathrm{TiO}_{2} \mathrm{NPs}$ in reducing cell survival in IM9

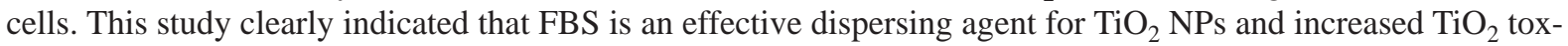
icity in all cell lines. NAC and neopterin significantly protected the SHYS5Y cell against the putative cytotoxic effects of $\mathrm{TiO}_{2}$ NPs.
\end{abstract}

Key words: $\quad \mathrm{TiO}_{2}$ nanoparticle, SHSY5Y, U937, IM9, neopterin, dexamethasone, N-acetyl cysteine

\section{Introduction}

Titanium and titanium dioxide $\left(\mathrm{TiO}_{2}\right)$ are extensively used for a wide range of implanted medical devices and variety of consumer product such as toothpastes, sunscreens, cosmetics, food products (1), paints and surface coatings and in the environmental decontamination of air, soil, and water (2). Such widespread use and its potential entry though dermal, ingestion, and inhalation routes suggest that nano-size $\mathrm{TiO}_{2}$ could pose an exposure risk to humans. Besides, a number of factors including particle size, chemical composition and surface charges also play role to determine the extent of nanoparticles (NPs) toxicity (3-5). Thus $\mathrm{TiO}_{2}$ nanoparticles are rapidly taken up by the cells and a significant increase in lactate dehydrogenase (LDH) release, apoptosis and mitochondrial membrane permeability may develop. In general, reactive oxygen

Correspondence to: Ayse Basak ENGIN, Assoc. Prof. Dr., Gazi University, Faculty of Pharmacy, Department of Toxicology, 06330, Hipodrom - Ankara - Turkey, Tel: +90 312202 3084, Fax: +90 312222 2326,

E-mail: abengin@gmail.com 
species (ROS) generation mediated oxidative stress and impaired antioxidant status has been suggested as major cause of cytotoxicity and genotoxicity of nanosize particles (NPs) $(6,7)$.

Several studies have reported that exposed NPs enter systemic circulation and migrate to various organs and tissues $(8,9)$ where they could accumulate and damage organ systems that are especially sensitive to oxidative stress. Among these, brain is one, being highly vulnerable to oxidative stress because of its energy demands, low levels of endogenous scavengers and high cellular concentration of oxidative stress targets. Actually NPs can cross the blood-brain barrier and enter the central nervous system (10) and may accumulate within the brain over long periods and trigger toxic effects (11). Consequently these particles may be associated with neurodegenerative diseases $(12,13)$ such as Alzheimer's disease (14), Parkinson's disease, Huntington's disease (15), and primary brain tumors (16). NPs induced ROS production could serve as messengers to trigger an endogenous program of cell death that may be promoted by multiple pathways. Terminally differentiated neurons might commit to death under conditions of oxidative stress (17). The final fate of the cell, life or death, would depend on the level, type or duration of oxidative stress and, more importantly, on the strength of the endogenous antioxidant mechanisms.

Available data in the literature showed that $\mathrm{TiO}_{2}$ NPs can cause several adverse effects on mammalian cells such as increase of ROS production and cytokines levels, reduction of cell viability and proliferation, induction of apoptosis and genotoxicity. However it is not known whether $\mathrm{TiO}_{2}$ NPs exert oxidative stress on dopaminergic (DE) neurons. Therefore additional research is needed to obtain advance knowledge on toxic effects of $\mathrm{TiO}_{2}$ NPs and to avoid any potential risk correlated to their exposure (18).

We hypothesized that $\mathrm{TiO}_{2} \mathrm{NP}$ can exert diverse cytotoxic effects on various human cell types especially neuronal cell lines. In order to test our hypothesis, putative cytotoxic effects of oxidative stress due to $\mathrm{TiO}_{2}$ NPs exposure on human neuroblastoma cells SHSY5Y were compared with IM9 (multiple myeloma cells, malignant disorder of differentiated B cells) and human histiocytic lymphoma cell line, U937 in the presence of antioxidant, N-acetyl cysteine (NAC), anti- or pro-oxidant, neopterin and oxidant-promoter agent dexamethasone.

\section{Materials and Methods}

\section{Cell culture}

The human leukemic monocyte lymphoma (U937) and human B-cell lymphoma (IM9) cell lines were obtained from Ankara University Biotechnology Institute and cultured in DMEM (Sigma-Aldrich Co.) supplemented with $10 \%$ fetal bovine serum (FBS), $0.2 \%$ sodium bicarbonate and $10 \mathrm{ml} / \mathrm{L}$ antibiotic and antimycotic solution (Penicillin-streptomycin, 100x, Invitrogen) at $37^{\circ} \mathrm{C}$ under a humidified atmosphere of $5 \% \mathrm{CO}_{2} / 95 \%$ air. Stock suspensions of $10 \mathrm{~nm}$ and 25 $\mathrm{nm}$ sized $\mathrm{TiO}_{2}$ NPs $(10 \mathrm{mg} / \mathrm{ml})$ in water and neuroblastoma cell line SHSY5Y were kindly provided by Dr. Nathalie Herlin-Boime (CEA-CNRS, Saclay, France) and Dr. Marie Carriere (CEA, Grenoble, France) as a gift to be used in the project entitled "Nanotoxicology Link Between India and European Nations" under the program New Indigo supported by FP7.

U937 and IM9 cells were cultured in DMEM (supplemented with $10 \%$ FBS), while SHSY5Y cells were incubated in Ham F12:EMEM (1:1) medium (SigmaAldrich Co.). The cells were incubated with NPs in three time points as 6, 24 and 48 hours. For 6 hours of incubation the cells were seeded in medium without FBS (incomplete medium) and the medium was supplemented with $10 \%$ FBS (complete medium) for the incubation periods of 6, 24 and 48 hours.

NP solutions were diluted with medium according to the cell line that is used. Ten concentrations ranging between $0.2-100 \mu \mathrm{g} / \mathrm{ml}$ were used to perform the 3 [4,5-dimethylthiazol-2-yl]-2,5 diphenyl tetrazolium bromide (MTT) assays. For each experiment, the particle suspension was freshly prepared, diluted to appropriate concentrations and immediately applied to the cells. Culture medium without $\mathrm{TiO}_{2}$ NPs served as the control in each experiment.

Cells were counted by using trypan blue for each time point and for each concentration in every assay condition.

\section{Cytotoxicity assays}

Cytotoxicity of $\mathrm{TiO}_{2}$ NPs was measured by using MTT. Cells $\left(10^{4}\right.$ cells/well $)$ were seeded in 96-well plates. Twenty four hours after seeding (one cell cycle), the cells were exposed to 10 different concentrations of $\mathrm{TiO}_{2}$ NPs $(0.2-100 \mu \mathrm{g} / \mathrm{ml})$ for three time periods, 6 (with and without FBS), 24 and 48 hours. All the assays performed in triplicates in three sets of experiments.

By the evaluation of the first experiment series, the NP doses and exposure periods were chosen for NAC, neopterin and dexamethasone assays. For further experiments, $10^{4}$ cells were seeded in 96 well plates; each set was individually pre-incubated for 30 minutes with $15 \mathrm{mM}$ NAC, 0.1 or $10 \mu \mathrm{M}$ neopterin or $1 \mu \mathrm{g} / \mathrm{dl}$ dexamethasone and after this period, $0.8 \mu \mathrm{g} / \mathrm{ml}, 50$ $\mu \mathrm{g} / \mathrm{ml}$ and $100 \mu \mathrm{g} / \mathrm{ml}, 25 \mathrm{~nm}$ and $10 \mathrm{~nm} \mathrm{TiO}_{2} \mathrm{NPs}$ were added and the cells were incubated for 24 hours in FBS 
containing medium. In all samples MTT assay was performed as described below.

\section{Mitochondrial activity}

Mitochondrial activity was assessed using the MTT assay according to a modified method of Mosmann (19). Briefly, cells were exposed to NPs for different time periods (6, 24 and 48 hours) and MTT dye $(0.5 \mathrm{mg} / \mathrm{ml})$ was added into each well 4 hours after the completion of incubation period. Thereafter, the reaction the resulting formazan crystals were solubilized by adding $\% 10 \mathrm{SDS}$ in $1 \mathrm{~N} \mathrm{HCl}$ solution. The interference of nanoparticles was obviated by centrifuging the plates, transferring the supernatant into a new plate and then measuring the absorbance at $550 \mathrm{~nm}$.

\section{Statistical Analysis}

The significance of the difference between control and compound treated cell groups were analysed by Mann-Whitney U test and $\mathrm{p}<0.05$ was considered statistically significant. The calculations were performed by using the statistical package SPSS, version 13.0 (SPSS Inc., Chicago, Illinois, USA).

\section{Statistical analysis}

The significance of the difference between control and compoud treated cell groups were analysed by Mann-Whitney U test and $\mathrm{p}<0.05$ was considered statistically significant. The calculations were performed by using the statistical package SPSS, version 13.0 (SPSS Inc., Chicago, Illinois, USA). plete medium (without FBS) for both nm 25 (from $94.75 \%$ to $134.47 \%$ ) and $10 \mathrm{~nm}$ (from $105.45 \%$ to $135.99 \%$ ) particles compared to complete medium (with FBS) (25 nm; from 90.6\% to $103.87 \%, 10 \mathrm{~nm}$; from $98.32 \%$ to $109.52 \%$ ). U937 cell lines also showed a similar pattern of cell viability curves during the 6-hours incubation period either with incomplete (25nm; from $96.47 \%$ to $131.07 \%, 10 \mathrm{~nm}$; from $91.77 \%$ to $122.31 \%$ ) or complete medium $(25 \mathrm{~nm}$; from $104.91 \%$ to $111.58 \%$, $10 \mathrm{~nm}$; from $91.77 \%$ to $96.29 \%$ ) at all $\mathrm{TiO}_{2}$ concentrations and for all particle sizes with the SHSY5Y cell lines. Consequently, $\mathrm{TiO}_{2} \mathrm{NPs}_{\text {sas }}$ found to be more toxic in the complete medium for SHSY5Y and U937 cell lines. $25 \mathrm{~nm} \mathrm{TiO}_{2}$ induced $27.46 \%$ increase in the viability of IM9 cell lines with complete medium and this figure dropped gradually to $21.91 \%$ at $100 \mu \mathrm{g} / \mathrm{ml}$ concentration of $\mathrm{TiO}_{2}$. Cell viability during the 6-hours incubation period of $25 \mathrm{~nm}$ $\mathrm{TiO}_{2}$ particles with IM9 cells in FBS-free medium increased gradually in a concentration-dependent manner from $111.96 \%$ (at $0.39 \mu \mathrm{g} / \mathrm{ml} \mathrm{TiO}_{2}$ concentration) reached to a maximum of $125.44 \%$ (at $100 \mu \mathrm{g} / \mathrm{ml}$ concentration). However, $10 \mathrm{~nm}$ diameter $\mathrm{TiO}_{2}$ particles showed similar toxicity pattern on IM9 cells with the other cell lines either in FBS-free (from $102.82 \%$ to $98.56 \%$ at $50 \mu \mathrm{g} / \mathrm{ml}$ and $108.43 \%$ at $100 \mu \mathrm{g} / \mathrm{ml}$ ) or FBS-containing (from $98.19 \%$ to $94.1 \%$ at $50 \mu \mathrm{g} / \mathrm{ml}$ and $107.41 \%$ at $100 \mu \mathrm{g} / \mathrm{ml}$ ) mediums. Addition of FBS in culture media significantly increased toxicity of 25nm and $10 \mathrm{~nm} \mathrm{TiO}_{2}$ particles on SHYS5Y, as well as U937 cell lines but in contrast to IM9 (Figure 1a-1c, 2a-2c, Table 1).

Table 1.: The concentration-dependent effects of $25 \mathrm{~nm}$ or $10 \mathrm{~nm} \mathrm{TiO}_{2}$ nanoparticles on viability of SHSY5Y, U937 and IM9 cells which were cultured in FBS-containing or FBS-free medium. Values indicated the differences of viability between $0.2 \mu \mathrm{g} / \mathrm{ml}$ and $100 \mu \mathrm{g} / \mathrm{ml}$ ten different concentrations of $\mathrm{TiO}_{2}$ at the end of 6-hour incubation period. $* \mathrm{p}<0.05$; comparison of $\%$ alteration in cell viability between medium without FBS and with FBS.

$\begin{array}{lc}\text { Cell line } & \text { Nanoparticle size }(\mathbf{n m}) \\ & \\ \text { SHSY5Y } & 25 \\ & 10 \\ \text { U937 } & 25 \\ & 10 \\ \text { IM9 } & 25 \\ & 10\end{array}$

\begin{tabular}{|c|}
\hline $\begin{array}{c}\text { Medium without FBS } \\
\text { (\% alteration in cell } \\
\text { viability) }\end{array}$ \\
\hline+6.82 \\
\hline+14.34 \\
\hline+7.23 \\
\hline+12.16 \\
\hline+16.62 \\
\hline+1.04 \\
\hline
\end{tabular}

\section{Results}

Diverse effect of fetal bovine serum (FBS) on viability of cell lines

Cell viability curve of SHSY5Y cells showed a sharp increase during the first 6-hours incubation period in concentration-dependent manner with the incom-
NP-induced oxidative stress and pro-inflammatory

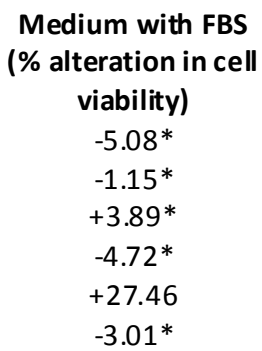
responses are well correlated not only with the physical properties of the individual NPs but also with the internalized amount of NPs (20). The MTT assay is based on the conversion of MTT into formazan crystals by living cells, which determines mitochondrial activity. For most cell populations the total mitochondrial activity is related to the number of viable cells 

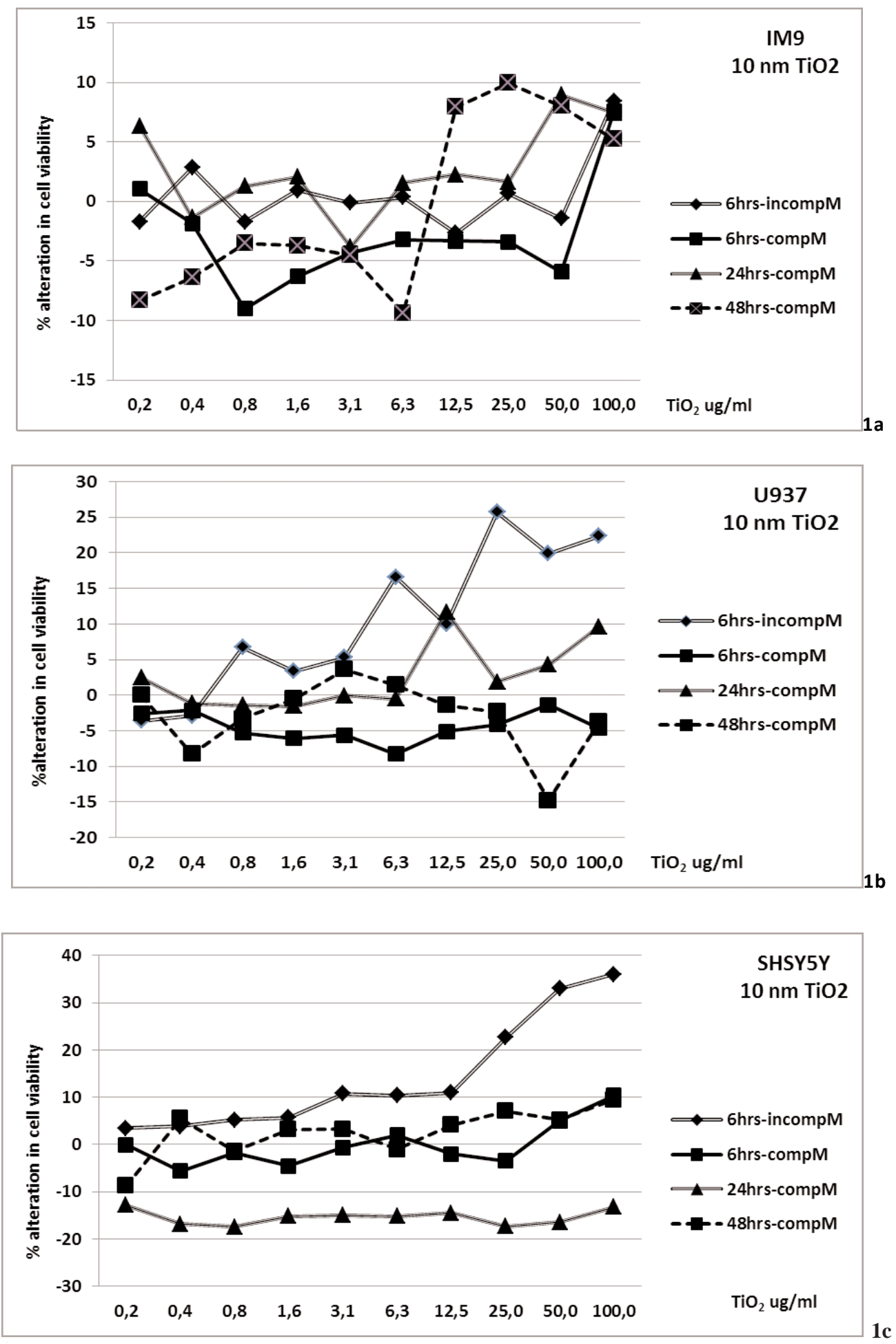

Figure 1.: \% alteration in cell viability of IM9 (a), U937 (b) and SHSY5Y (c) cells after exposure to $10 \mathrm{~nm} \mathrm{TiO}_{2}$ nanoparticles.

(21). When the conversion of MTT into formazan crystals by living cells was divided by the simultaneous cell number at concentrations $0.8,50$ and $100 \mu \mathrm{g} / \mathrm{ml}$
$\mathrm{TiO}_{2}$, resultant viability percentile gives the steady state mitochondrial activity per viable cell (Table 2 ). 

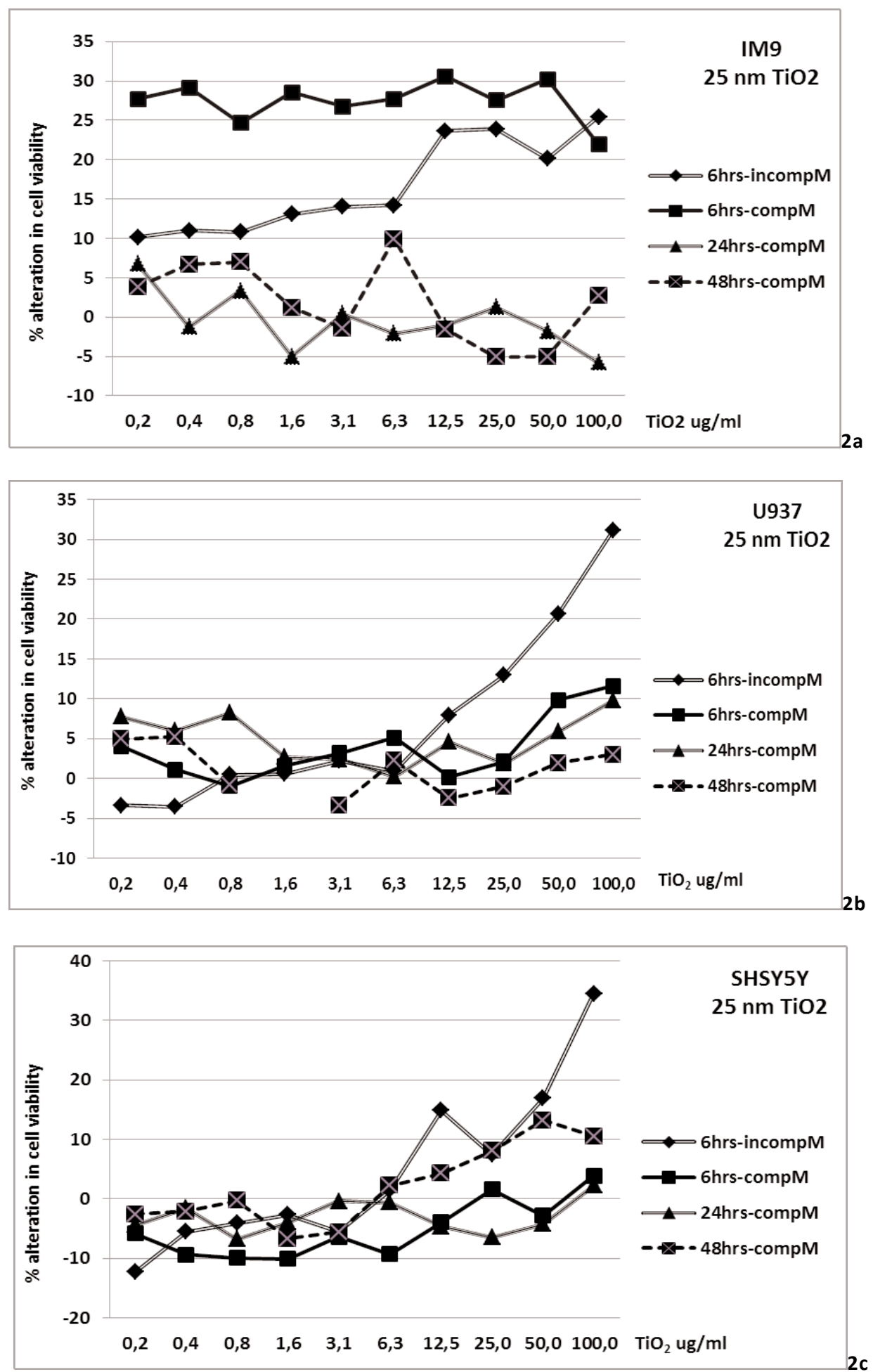

Figure 2.: \% alteration in cell viability of IM9 (a), U937 (b) and SHSY5Y (c) cells after exposure to $25 \mathrm{~nm} \mathrm{TiO}_{2}$ nanoparticles.

The protective effects of NAC against $\mathrm{TiO}_{2}$ cytotoxicity

While the IM9 cells pre-incubated with NAC and followed by exposure to $25 \mathrm{~nm} \mathrm{TiO}_{2}$-NPs (at $0.8,50$ and $100 \mu \mathrm{g} / \mathrm{ml}$ concentrations) showed slight decreases in cell viability, exposure to $10 \mathrm{~nm} \mathrm{TiO}{ }_{2}$-NPs were 
Table 2.: Metabolic activities of SHSY5Y, U937 and IM9 cell lines are indicated by cell viability percentile per cell for three different concentrations of $25 \mathrm{~nm}$ and $10 \mathrm{~nm} \mathrm{TiO}_{2}$ nanoparticles vs. controls at the end of $24 \mathrm{~h}$ incubation period.

*: p <0.05; $0.8 \mu \mathrm{g} / \mathrm{ml}$ vs $50 \mu \mathrm{g} / \mathrm{ml}$, **: p <0.05; $0.8 \mu \mathrm{g} / \mathrm{ml}$ vs $100 \mu \mathrm{g} / \mathrm{ml}$, ***: p <0.05; $50 \mu \mathrm{g} / \mathrm{ml}$ vs $100 \mu \mathrm{g} / \mathrm{ml}$, $* * * * ; \mathrm{p}<0.05 ; \mathrm{TiO}_{2}$-treated group vs. controls

NP: Nanoparticle

V(\%)/Cc: Cell viability \% / Cell count

\begin{tabular}{|c|c|c|c|c|}
\hline $\mathrm{TiO}_{2}$ NPs & NPs & SHSY5Y & U937 & IM9 \\
\hline Size (nm) & $(\mu \mathrm{g} / \mathrm{ml})$ & $\mathrm{V}(\%) / \mathrm{Cc}$ & $\mathrm{V}(\%) / \mathrm{Cc}$ & $\mathrm{V}(\%) / \mathrm{Cc}$ \\
\hline \multirow{4}{*}{25} & Control & 0.8 & 0.9 & 0.9 \\
\hline & 100 & $0.6^{* * * *}$ & 0.8 & 0.9 \\
\hline & 50 & $0.6 * * * *$ & 0.9 & 0.9 \\
\hline & 0.8 & $0.4 *, * *, * * * *$ & $0.5^{*, * *, * * * *}$ & $0.8^{*, * *, * * * *}$ \\
\hline \multirow{4}{*}{10} & Control & 0.8 & 0.9 & 0.8 \\
\hline & 100 & 0.7 & 0.8 & 0.8 \\
\hline & 50 & $0.6 * * *$ & $0.9 * * *$ & $0.9 * * *, * * * *$ \\
\hline & 0.8 & $0.5 *, * *, * * * *$ & $0.7^{*, * *, * * * *}$ & $0.9 *, * *, * * * *$ \\
\hline
\end{tabular}

more toxic. Although NAC pre-treated U937 cell lines showed a slight decrease in the viability at any concentration and at any particle size during the 24-hour incubation period, $10.23 \%$ increase was observed with only $50 \mu \mathrm{g} / \mathrm{ml}$ concentration of $25 \mathrm{~nm} \mathrm{TiO} 2$. Whereas NAC showed significant ( $\mathrm{p}<0.05$, Table 3 ) protection in viability of SHSY5Y cell exposed to $25 \mathrm{~nm} \mathrm{TiO}_{2}$ NPs (at $0.8,50$ and $100 \mu \mathrm{g} / \mathrm{ml}$ concentrations) with a striking increase in viability percentiles for $0.8 \mu \mathrm{g} / \mathrm{ml}$; $136.35 \%$, for $50 \mu \mathrm{g} / \mathrm{ml} ; 135.74 \%$, for $100 \mu \mathrm{g} / \mathrm{ml}$; $133.36 \%$ were measured after long-term, 24-hour incubation period. NAC pre-treatment significantly protected the SHSY5Y cells against $\mathrm{TiO}_{2}$ NPs toxicity, at any size and at any concentration of $\mathrm{TiO}_{2}$ (Table 3).

\section{Effect of neopterin on cell viability}

IM9 and U937 cells pre-incubated with neopterin
$(0.1 \mu \mathrm{M}, 10 \mu \mathrm{M})$ receiving long term (24 hours) exposure of $25 \mathrm{~nm} \mathrm{TiO}_{2}$-NPs (at $0.8,50$ and $100 \mu \mathrm{g} / \mathrm{ml}$ concentrations) showed more or less similar magnitude and trends of viability curves as observed in exposure to $10 \mathrm{~nm} \mathrm{TiO}_{2}$-NPs at $0.8,50$ and $100 \mu \mathrm{g} / \mathrm{ml}$ concentrations. Whereas SHSY5Y cell pre-treated with 0.1 or $10 \mu \mathrm{M}$ neopterin, displayed significant $(\mathrm{p}<0.05)$ increases in viability with 10 and $25 \mathrm{~nm} \mathrm{TiO}_{2}$ NPs at 0.8 and $50 \mu \mathrm{g} / \mathrm{ml}$ concentrations (Table 4). In contrast to $10 \mu \mathrm{M}, 0.1 \mu \mathrm{M}$ neopterin could not protect SHSY5Y cells against the toxic effects of $25 \mathrm{~nm} \mathrm{TiO}_{2}$ nanoparticles, at $100 \mu \mathrm{g} / \mathrm{ml}$ concentration. $10 \mu \mathrm{M}$ neopterin increased the viability of IM9 cells following $25 \mathrm{~nm} \mathrm{TiO}_{2}$ NPs exposure at $100 \mu \mathrm{g} / \mathrm{ml}$ and $10 \mathrm{~nm}$ nanoparticles exposure at $0.8 \mu \mathrm{g} / \mathrm{ml}$ concentration. On the other hand $0.1 \mu \mathrm{M}$ neopterin increased the viability of IM9 cells following $25 \mathrm{~nm}$ and $10 \mathrm{~nm} \mathrm{TiO}_{2}$ NPs exposure at 100

Table 3.: The effect of two different sizes of $\mathrm{TiO}_{2} \mathrm{NPs}$ on cell viability of $\mathrm{N}$-acetyl cysteine pretreated cell lines vs. $\mathrm{TiO}_{2}$-treated only

** Increase in cell viability (per cent) at the end of the 24-hour incubation period.

\#The mean value of cell viabilities (per cent) for ten different concentrations (from $0.2 \mu \mathrm{g} / \mathrm{ml}$ to $100 \mu \mathrm{g} / \mathrm{ml}$ ) of $\mathrm{TiO}_{2}$ NPs at the end of the 24-hour incubation period.

$* \mathrm{p}<0.05$; NAC treated group compared to mean value of cell viabilities.

$\mathrm{N}$-acetyl cysteine pretreatment (15mM)

$\begin{array}{lccccc}\text { Cell line } & \begin{array}{c}\text { Nanoparticle } \\ \text { size }(\mathrm{nm})\end{array} & \begin{array}{c}0.8 \mu \mathrm{g} / \mathrm{ml} \mathrm{TiO} 2 \\ (\mathrm{CV} \%)^{* *}\end{array} & \begin{array}{c}50 \mu \mathrm{g} / \mathrm{ml} \mathrm{TiO}_{2} \\ (\mathrm{Cv} \%)^{* *}\end{array} & \begin{array}{c}100 \mu \mathrm{g} / \mathrm{ml} \mathrm{TiO}_{2} \\ (\mathrm{Cv} \%)^{* *}\end{array} & \mathrm{TiO}_{2} \#(\mathbf{C v \%})^{* *} \\ \text { SHSY5Y } & 25 & 136.35^{*} & 135.74^{*} & 133.36^{*} & -3.51 \\ & 10 & 127.10^{*} & 130.11^{*} & 129.57^{*} & -15.38 \\ \text { U937 } & 25 & 0.79 * & 10.23^{*} & -0.14 & 4.87 \\ & 10 & -0.64 & -3.98 & -2.84 & 2.67 \\ \text { IM9 } & 25 & -2.82 & -1.26^{*} & -1.26^{*} & -0.75 \\ & 10 & -14.10^{*} & -10.07 & -13.25 & 2.57\end{array}$


Table 4.: The effect of two different sizes of $\mathrm{TiO}_{2} \mathrm{NPs}$ on cell viability of neopterin pre-treated cell lines $\mathrm{vs} \mathrm{TiO}_{2^{-}}$ treated only.Re

** Increase in cell viability (per cent) at the end of the 24-hour incubation period.

\# The mean value of cell viabilities (per cent) for ten different concentrations (from $0.2 \mu \mathrm{g} / \mathrm{ml}$ to $100 \mu \mathrm{g} / \mathrm{ml}$ ) of $\mathrm{TiO} 2 \mathrm{NPs}$ at the end of the 24-hour incubation period.

$* \mathrm{p}<0.05$; Neopterin treated group compared to mean value of cell viabilities.

\begin{tabular}{|c|c|c|c|c|c|c|c|c|}
\hline \multirow[b]{2}{*}{ Cell line } & \multicolumn{8}{|c|}{ Neopterin pre-tre atment } \\
\hline & $\begin{array}{c}\text { NPs size } \\
(\mathrm{nm})\end{array}$ & $\begin{array}{c}0.8 \\
\mu \mathrm{g} / \mathrm{ml} \\
\mathrm{Cv} \% * *\end{array}$ & $\begin{array}{c}0.1 \mathrm{uM} \\
50 \\
\mu \mathrm{g} / \mathrm{ml} \\
\text { Cv \%** }\end{array}$ & $\begin{array}{c}100 \\
\mu \mathrm{g} / \mathrm{ml} \\
\mathrm{Cv} \% * *\end{array}$ & $\begin{array}{c}0.8 \\
\mu \mathrm{g} / \mathrm{ml} \\
\mathrm{Cv} \% * *\end{array}$ & $\begin{array}{c}10 \mathrm{uM} \\
50 \\
\mu \mathrm{g} / \mathrm{ml} \\
\mathrm{CV} \% * *\end{array}$ & $\begin{array}{c}100 \\
\mu \mathrm{g} / \mathrm{ml} \\
\mathrm{Cv} \%{ }^{* *}\end{array}$ & $\mathrm{TiO}_{2} \#(\mathrm{Cv} \%)^{* *}$ \\
\hline & 25 & $13.14 *$ & $6.42 *$ & -0.66 & $13.14 *$ & $50.89 *$ & $33.46 *$ & -3.51 \\
\hline SHSYSY & 10 & $-4.6^{*}$ & $-4.89 *$ & $3.87 *$ & $-8.84 *$ & $-4.89 *$ & $-10.61 *$ & -15.38 \\
\hline U937 & $\begin{array}{l}25 \\
10\end{array}$ & $\begin{array}{l}-5.91^{*} \\
-2.80^{*}\end{array}$ & $\begin{array}{c}-1.87^{*} \\
2.10\end{array}$ & $\begin{array}{l}7.43 \\
6.92\end{array}$ & $\begin{array}{l}-7.09 * \\
-0.64\end{array}$ & $\begin{array}{l}1.13 \\
6.79\end{array}$ & $\begin{array}{l}4.94 \\
6.92\end{array}$ & $\begin{array}{l}4.87 \\
2.63\end{array}$ \\
\hline IM9 & $\begin{array}{l}25 \\
10\end{array}$ & $\begin{array}{c}0.94 \\
-1.98\end{array}$ & $\begin{array}{c}7.96^{*} \\
3.79\end{array}$ & $\begin{array}{l}10.91^{*} \\
14.12^{*}\end{array}$ & $\begin{array}{c}0.94 \\
-6.44 *\end{array}$ & $\begin{array}{l}5.83 \\
3.79\end{array}$ & $9.40^{*}$ & $\begin{array}{r}-0.75 \\
2.57\end{array}$ \\
\hline
\end{tabular}

$\mu \mathrm{g} / \mathrm{ml}$ concentrations. Pre-treatment of IM9 and U937 cell lines with neopterin suggested that increase in particle size and most probably mismatch between FBS and particle concentrations might be argued considering irregular course of particles and cell lines interaction. In vitro-studies revealed that neopterin exhibits distinct biochemical effects, via interactions with reactive oxygen or nitrogen intermediates, thereby affecting the cellular redox state (22). However of all oxidation states have been shown to act anti- or pro-oxidatively, depending on the special conditions of the experiment (23).

\section{Effect of dexamethasone on cell viability}

U937 cells pre-incubated with dexamethasone, $1 \mu \mathrm{g} / \mathrm{ml}$, at supraphysiological dose (24); received long term (24 hours) exposure of either $25 \mathrm{~nm}$ or $10 \mathrm{~nm}$
$\mathrm{TiO}_{2}$-NPs (at $0.8,50$ and $100 \mu \mathrm{g} / \mathrm{dl}$ concentrations) showed more or less similar magnitude and trends of viability curves with both particle sizes. While $25 \mathrm{~nm}$ $\mathrm{TiO}_{2}$ NPs increased the viability of dexamethasone pretreated U937 cells at a rate of $16.1 \%, 10 \mathrm{~nm} \mathrm{TiO}{ }_{2}$ NPs enhanced the cell viability by $7.42 \%$ at $100 \mu \mathrm{g} / \mathrm{ml}$ $\mathrm{TiO}_{2}$ NPs concentration. Maximum response of dexamethasone pre-treated IM9 cells was $4.2 \%$ increase in cell viability to $25 \mathrm{~nm} \mathrm{TiO}{ }_{2}$ NPs challenge at $50 \mu \mathrm{g} / \mathrm{ml}$ concentrations. Similarly it was $3.79 \%$ for $10 \mathrm{~nm} \mathrm{TiO}{ }_{2}$ NPs. We could not estimate constant increase in cell viability of SHSY5Y cell line with dexamethasone pre-treatment at all concentrations for $25 \mathrm{~nm}$ particles (Table 5). However, dexamethasone provided a considerable protection at all particle concentrations for 10 $\mathrm{nm}$ nanoparticles. Data collected from this study demonstrated variable response to cortisol by IM9 and

Table 5.: The effect of two different sizes of $\mathrm{TiO}_{2} \mathrm{NPs}$ on cell viability of dexamethasone pre-treated cell lines vs. $\mathrm{TiO}_{2}$-treated only

** Increase in cell viability (per cent) at the end of the 24-hour incubation period.

\#The mean value of cell viabilities (per cent) for ten different concentrations (from $0.2 \mu \mathrm{g} / \mathrm{ml}$ to $100 \mu \mathrm{g} / \mathrm{ml}$ ) of $\mathrm{TiO}_{2} \mathrm{NPs}$ at the end of the 24-hour incubation period.

$* p<0.05$; Dexamethasone treated group compared to mean value of cell viabilities.

Dexamethasone $(1 \mu \mathrm{g} / \mathrm{dl})$

\begin{tabular}{|c|c|c|c|c|c|}
\hline Cell line & $\begin{array}{l}\text { NPs size } \\
(\mathrm{nm})\end{array}$ & $\begin{array}{c}0.8 \mu \mathrm{g} / \mathrm{ml} \\
(\mathrm{Cv} \%)^{* *}\end{array}$ & $\begin{array}{c}50 \mu \mathrm{g} / \mathrm{ml} \\
(\mathrm{Cv} \%)^{* *}\end{array}$ & $\begin{array}{c}100 \mu \mathrm{g} / \mathrm{ml} \\
(\mathrm{Cv} \%)^{* *}\end{array}$ & $\mathrm{TiO}_{2} \#(\mathrm{Cv} \%)^{* *}$ \\
\hline \multirow{2}{*}{ SHSY5Y } & 25 & -1.59 & -1.01 & $6.17^{*}$ & -3.51 \\
\hline & 10 & $-0.34^{*}$ & $-0.39 *$ & $3.87^{*}$ & -15.38 \\
\hline \multirow{2}{*}{ U937 } & 25 & $0.79 *$ & 2.92 & $16.10^{*}$ & 4.87 \\
\hline & 10 & -2.31 & 3.98 & 7.42 & 2.60 \\
\hline \multirow{2}{*}{ IM9 } & 25 & 2.92 & 4.20 & 2.71 & -0.75 \\
\hline & 10 & $-6.44^{*}$ & 3.79 & -1.82 & 2.57 \\
\hline
\end{tabular}


U937 cell lines versus SHSY5Y cells.

\section{Discussion}

Although the factors responsible for the generation of oxidative stress in DE neurons and the mechanisms of DE neuron cell death have not yet been elucidated in neurodegenerative diseases, postmortem examination of brain revealed that loss of DE neurons in the nigro-striatal region is due to increased oxidative stress $(25,26)$. In this case, stable and reliable DE neuronal cell model is particularly necessary for studying the pathogenesis of neurodegenerative diseases. Presently, an ideal in vitro neuronal cell model established in post-mitotic human DE neuronal cells is human neuroblastoma (SHSY5Y) cell lines (27). The SHSY5Y cell line provides an unlimited supply of cells of human origin with the similar biochemical characteristics to human DE neurons. Consequently, the SHSY5Y cell line has been widely used in experimental neurological studies, including analysis of neuronal differentiation, metabolism, and function related to neurodegenerative processes and neurotoxicity of DE neurons in the brain (28).

Oxidative stress-induced neuronal death may be promoted via several pathways (17). In this context, NPs-induced oxidative stress and pro-inflammatory responses are well correlated not only with the surface area of the individual NPs but also with the internalized amount of NPs. Actually differences of primary particle size leads to significant changes in inflammatory and oxidative stress responses (20). In fact size and surface area of particles are integral part of their toxicity. $\mathrm{TiO}_{2}$ particle toxicity has been repeatedly investigated and observed showed that particle toxicity increases as particle size decreases (29). However it is relevant that a high degree of particle aggregation and agglomeration is associated with $\mathrm{TiO}_{2}$ administration, and so exposure to particles is unlikely to occur in a 'nano' form. Grassian et al. showed that specifically, $21 \mathrm{~nm}$ particle based agglomerates were less dense than their $5 \mathrm{~nm}$ counterparts whose agglomerates contained particles that are more tightly packed. Therefore, it was found that $21 \mathrm{~nm} \mathrm{TiO}_{2}$ was more toxic than $5 \mathrm{~nm}$ particles. Consequently, although 21 $\mathrm{nm}$ particles were larger, it is anticipated that they would form agglomerates that would more easily deagglomerate due to the weaker interactions that hold the particles together (30). Furthermore compared with fine particles, ultrafine particles exhibited greater free radical activity, greater inhibition of the reduction of MTT and a depletion of reduced glutathione (31). In our study we used two different sizes of ultrafine particles. Significant decrease in cell viabilities were observed in SHSY5Y and U937 cells lines with FBS plus $25 \mathrm{~nm}$ or $10 \mathrm{~nm}$ particles. However, SHSY5Y cells showed a greater reduction in cell viability when exposed to $10 \mathrm{~nm}$ particles than that of U937 and IM9 cells lines. The addition of FBS in medium most probably prevented high agglomeration, leading to a stable dispersion of $\mathrm{TiO}_{2}$ NPs and facilitated the internalization of the particles and increased $\mathrm{TiO}_{2}$ toxicity. Changes of surface properties by coating of nano-particles to prevent aggregation or agglomeration with different types and concentrations of serum proteins have been shown to change their body distribution and the effects on the biological systems significantly (32). While a significant decrease in metabolic activity was observed with $25 \mathrm{~nm}$ particles at $0.8 \mu \mathrm{g} / \mathrm{ml}$ concentration only, $10 \mathrm{~nm}$ particles caused metabolic alterations in both 0.8 and $50 \mu \mathrm{g} / \mathrm{ml}$ concentrations in all cell lines. This means that 10 per cent FBS seems insufficient to provide complete agglomeration of $25 \mathrm{~nm}$ particles at above the $0.8 \mu \mathrm{g} / \mathrm{ml}$ particle concentrations (Table 2). These result clearly indicated that FBS increased $\mathrm{TiO}_{2}$ toxicity for all cell lines. FBS may be an effective dispersing agent for $\mathrm{TiO}_{2} \mathrm{NPs}$ and strengthens particle effects. Thus the addition of enough FBS likely prevents high agglomeration leading to a stable dispersion of $\mathrm{TiO}_{2}$ nanoparticles due to steric stabilization and most probably facilitates the internalization of the particles and increased metal toxicity $(33,34)$.

In general, ROS mediated oxidative stress and impaired antioxidant status has been suggested as major cause of cytotoxicity and genotoxicity of NPs. $\mathrm{TiO}_{2}$ NPs were able to generate elevated amounts of free radicals, which induced indirect genotoxicity mainly by DNA-adduct formation, (6). In the present study, $\mathrm{TiO}_{2}$ toxicity was significantly reversed by NAC pre-treatment in SHSY5Y cells. However despite NAC pre-treatment, cell viability of U937 and IM9 cells decreased remarkably. Oda et al. examined the effect of NAC at concentrations of 5 to $20 \mathrm{mM}$ on the cell death induced by the cytotoxic protein ricin in U937 cells. Interestingly, NAC significantly prevented ricin-induced toxicity at $20 \mathrm{mM}$, even though the cellular reduced glutathione (GSH) level was decreased to less than 5\%. These results suggested that protective effect of NAC at only appropriate concentrations is mediated through affecting the cellular thiol/disulfide status via acting as a thiol supplier in U937 cells (35). Pre-treatment with $15 \mathrm{mM}$ NAC is thought to be an insufficient concentration to supply thiols in U937 cells. Indeed, it has been shown that treatment of U937 cells with NAC increases intracellular anti-oxidant capacity but have little effect on the absolute or relative toxicity's of the metals (36). Likewise our study confirmed that the human myeloid cell line, U937 has 
still increased sensitivity to $\mathrm{TiO}_{2}$ in spite of the NAC pre-treatment. Ultra-fine $\mathrm{TiO}_{2}$ particles causing inflammation can increase the manganese superoxide dismutase (MnSOD) mRNA levels (37). Intra- mitochondrial MnSOD activity and mitochondria-derived ROS levels regulate cellular proliferation and hydrogen peroxide $\left(\mathrm{H}_{2} \mathrm{O}_{2}\right)$-signaling (38). NAC reacts with hydroxyl radical and $\mathrm{H}_{2} \mathrm{O}_{2}$, but no reaction of NAC with superoxide could be detected (39). Consequently NAC exposure increases the steady-state levels of superoxide by two-fold. Cells respond to this increase in the superoxide levels by increasing MnSOD activity. Increase in MnSOD activity corresponds to an increase in $\mathrm{H}_{2} \mathrm{O}_{2}$ levels. Because higher levels of $\mathrm{H}_{2} \mathrm{O}_{2}$ are growth inhibitory, it could play a role in regulating NAC-induced G1 arrest. The G1 checkpoint is where eukaryotes typically arrest the cell cycle if environmental conditions make cell division impossible or if the cell passes into G0 for an extended period (40). However, increased thiol pools did not seem to regulate G1 arrest (41). NAC-induced increase in cellular superoxide levels is also associated with a decrease in cyclin D1 protein levels. In addition to reduction in cyclin D1 levels as an early response to NAC-exposures, a late response to NAC exposure is the increase in MnSOD protein levels and activity. This late response of MnSOD could be due to cellular responses to NAC-induced increase in superoxide levels resulting in G1 arrest. NAC exposures selectively increase MnSOD activities without altering CuZnSOD activity (40).

NAC-mediated restorations are associated with NAC dose-dependent increase of intracellular GSH level and a NAC dose-dependent decrease of intracellular ROS (42). Actually the glutathione system is very important for cellular defense against ROS and other forms of stress (43). The ratio of GSH to oxidized glutathione (GSSG) is critical for cellular redox balance, since it maintains the redox environment of the cell and it serves as an indicator of the cellular redox state. The majority of the GSH in cells is found in the cytoplasm, but mitochondria and nuclei have separate, independent pools of GSH (44). The decrease of mitochondrial GSH level (without changing the cytoplasmic pool of GSH) sensitizes several types of cells to oxidative stress (45). Significant increase in cell viability of SHSY5Y cells might be due to GSH sparing effect of $\mathrm{NAC}$ against $\mathrm{TiO}_{2}$-induced oxidative stress.

ROS also have a mediation effect to oxidative stress and up-regulation of c-Jun $\mathrm{NH}_{2}$-terminal kinase and p53 phosphorylation involved in mechanistic pathways of $\mathrm{TiO}_{2} \mathrm{NPs}$ and they can induce apoptosis and cell cycle arrest (46). NAC can inhibit activation of cJun N-terminal kinase, p38 MAP kinase and redoxsensitive activating protein- 1 and nuclear factor kappa
B transcription factor activities, thus regulating expression of numerous genes. On the other hand NAC also prevent apoptosis and promote cell survival by activating extracellular signal-regulated kinase pathway (47).

Glucocorticoid-dependent increase of oxidative stress in epithelial cell lines is antagonized by antioxidative enzymes such as catalase and/or preferentially by the glutathione system (48). Dexamethasone can increase cellular sensitivity to oxidative stress and alter the phenotype of neural stem cells (49). The cellular sensitivity to glucocorticoids is directly proportional to the concentration of receptor protein. In most cells, glucocorticoids promote a reduction in glucocorticoid receptors levels by a process termed homologous down regulation. Thus, glucocorticoid receptors of U937 cells are homologously down-regulated and may play a role in attenuating hormone responsiveness (50, 51). However in our study U937 and IM9 cells showed an irregular response to $\mathrm{TiO}_{2} \mathrm{NPs}$ after dexamethasone treatment in contrast to SHSY5Y cells. Viability of dexamethasone pre-treated SHSY5Y cells significantly increased in concentration dependent manner for 10 $\mathrm{nm} \mathrm{TiO}_{2}$ particles added medium during the 24-hour incubation period. Most probably dexamethasone pretreatment increased SHSY5Y cell-viability due to the internalization-defect at high concentration of $25 \mathrm{~nm}$ particles.

In vitro-studies revealed that neopterin derivatives exhibit distinct biochemical effects, most likely via interactions with reactive oxygen or nitrogen intermediates, thereby affecting the cellular redox state (22). The amounts of neopterin produced by activated monocytes/macrophages correlate with their capacity to release ROS. With this background, neopterin concentrations in body fluids can be regarded as an indirect estimate of the degree of oxidative stress emerging during cell-mediated immune response (52). Pteridines of all oxidation states have been shown to act anti- or pro-oxidatively, depending on the special conditions of the experiment. The reason is that reduced pteridines, besides of being scavengers of free radicals, also are strong reducing agents (23). Increased formation of neopterin in patients with DE neuron diseases are attributed to activated cell-mediated immune response. In our study $\mathrm{TiO}_{2}$ exposed SHSY5Y cells displayed $36 \%$ and $7.26 \%$ increase in cell viability with $25 \mathrm{~nm}$ and $10 \mathrm{~nm}$ particles exposure, respectively after $10 \mu \mathrm{M}$ neopterin treatment during 24-hour incubation period. $\mathrm{TiO}_{2}$ particles could be easily translocated into the cerebral cortex and striatum. Subsequently, exposure to $\mathrm{TiO}_{2} \mathrm{NPs}$ causes obvious morphological changes of neurons in the cerebral cortex (53). Since neopterin is elevated in the cerebrospinal fluid of patients with inflammatory neurological disorders, the source of neopterin was investigated in the brain and a possible 
contribution of biological active pteridines to the development of brain lesions. Consequently infiltrating monocytes/macrophages into the brain might be responsible for neopterin level in cerebrospinal fluid. In contrast to our results, Speth et al. did not observe an increase in the viability of brain cells exposed to neopterin (54).

\section{Conclusion}

Widely used nanomaterial, $\mathrm{TiO}_{2}$ has in-vitro neurotoxicity on cultured DE neuronal cells, SHSY5Y due to oxidative stress. Our results provide the evidence that oxidative effect induced by ultrafine $\mathrm{TiO}_{2}$ particles exposure can be completely suppressed by pre-incubation of SHSY5Y cells with the well-known antioxidant, NAC and partially suppressed with neopterin. One of the promising targets for preventing neurons from toxic side effects of accumulated $\mathrm{TiO}_{2}$ NPs may be neutralizing cellular oxidative stress with antioxidant agent.

\section{Acknowledgement}

We are grateful to Dr. Nathalie Herlin-Bomie and Dr. Marie Carriere who provided titanium dioxide nanoparticles and SHSY5Y cell line as a gift to be used in the project entitled "Nanotoxicology Link Between India and European Nations" under the program New Indigo supported by FP7.

This study was supported by Gazi University, Scientific Research Projects Division, 02/2012-23.

\section{Author Discloser Statement}

All authors disclose that they have any financial or personal relationships with other people or organizations. There is no direct financial interest in the subject matter or materials discussed in the manuscript that could inappropriately influence the work submitted. No competing financial interests exist.

\section{References}

1 Kaida T, Kobayashi K, Adachi M, Suzuki F. Optical characteristics of titanium oxide interference film and the film laminated with oxides and their applications for cosmetics. J Cosmet Sci 2004; 55:219-220.

2 Esterkin CR, Negro AC, Alfano OM, Cassano AE. Air pollution remediation in a fixed bed photocat- alytic reactor coated with $\mathrm{TiO}_{2}$. AIChE J 2005; 51: 2298-2310.

3 Thevenot P, Cho J, Wavhal D, Timmons RB, Tang L. Surface chemistry influences cancer killing effect of $\mathrm{TiO}_{2}$ nanoparticles. Nanomedicine 2008; 4: 226-236.

4 Yang H, Liu C, Yang D, Zhang H, Xi Z . Comparative study of cytotoxicity, oxidative stress and genotoxicity induced by four typical nanomaterials: the role of particle size, shape and composition. J Appl Toxicol 2009; 29: 69-78.

5 Fubini B, Ghiazza M, Fenoglio I. Physico-chemical features of engineered nanoparticles relevant to their toxicity. Nanotoxicology 2010; 4: 347-363.

6 Bhattacharya K, Davoren M, Boertz J, Schins RP, Hoffmann E, Dopp E. Titanium dioxide nanoparticles induce oxidative stress and DNA-adduct formation but not DNA-breakage in human lung cells. Part Fibre Toxicol 2009; 21: 6:17.

7 Asha Rani PV, Low Kah Mun G, Hande MP, Valiyaveettil S. Cytotoxicity and genotoxicity of silver nanoparticles in human cells. ACS Nano 2009; 3: 279-290.

8 Kreyling WG, Semmler M, Erbe F, Mayer P, Takenaka S, Schulz H, Oberdörster G, Ziesenis A. Translocation of ultrafine insoluble iridium particles from lung epithelium to extrapulmonary organs is size dependent but very low. J Toxicol Environ Health A 2002; 65: 1513-1530.

9 Takenaka S, Karg E, Roth C, Schulz H, Ziesenis A, Heinzmann U, Schramel P, Heyder J. Pulmonary and systemic distribution of inhaled ultrafine silver particles in rats. Environ. Health Perspect. 2001, 109, $547 ? 551$.

10 Lockman PR, Koziara JM, Mumper RJ, Allen DD. Nanoparticle surface charges alter blood-brain barrier integrity and permeability. J Drug Target 2004; 12: 635-641.

$11 \mathrm{Hu}$ YL, Gao JQ. Potential neurotoxicity of nanoparticles. Int J Pharm 2010; 394: 115?121.

12 Block ML, Wu X, Pei Z, Li G, Wang T, Qin L, Wilson B, Yang J, Hong JS, Veronesi B. Nanometer size diesel exhaust particles are selectively toxic to dopaminergic neurons: The role of microglia, phagocytosis, and NADPH oxidase. FASEB J 2004; 18: 1618-1620.

13 Peters A, Veronesi B, Calderon-Garciduenas L, Gehr P, Chen LC, Geiser M, Reed W, RothenRutishauser B, Schurch S, Schulz H. Translocation and potential neurological effects of fine and ultrafine particles, A critical update. Part Fibre Toxicol 2006; 3: 1-13.

14 Farrer LA. Intercontinental epidemiology of Alzheimer disease: A global approach to bad gene 
hunting. JAMA 2001; 285: 796-798.

15 Matés JM, Pérez-Gómez C, Núnez de Castro I. Antioxidant enzymes and human diseases. Clin Biochem 1999; 32: 595-603.

16 Orringer DA, Koo YE, Chen T, Kopelman R, Sagher O, Philbert MA. Small solutions for big problems: The application of nanoparticles to brain tumor diagnosis and therapy. Clin Pharmacol Ther 2009; 85: 531-534.

17 Langley B, Ratan RR. Oxidative stress-induced death in the nervous system: cell cycle dependent or independent? J Neurosci Res 2004; 77: 621-629.

18 Lavicoli I, Leso V, Fontana L, Bergamaschi A. Toxicological effects of titanium dioxide nanoparticles: a review of in vitro mammalian studies. Eur Rev Med Pharmacol Sci 2011; 15: 481-508.

19 Mosmann T. Rapid colorimetric assay for cellular growth and survival: application to proliferation and cytotoxic assays. J Immunol Meth 1983; 65: 55-63.

20 Hussain S, Boland S, Baeza-Squiban A, Hamel R, Thomassen LC, Martens JA, Billon-Galland MA, Fleury-Feith J, Moisan F, Pairon JC, Marano F. Oxidative stress and proinflammatory effects of carbon black and titanium dioxide nanoparticles: role of particle surface area and internalized amount. Toxicology 2009; 260: 142-149.

21 Van Meerloo J, Kaspers GJ, Cloos J. Cell sensitivity assays: the MTT assay. Methods Mol Biol 2011; 731: 237-245.

22 Hoffmann G, Wirleitner B, Fuchs D. Potential role of immune system activation-associated production of neopterin derivatives in humans. Inflamm Res 2003; 52: 313-321.

23 Oettl K, Reibnegger G. Pteridine derivatives as modulators of oxidative stress. Curr Drug Metab 2002; 3: 203-209.

24 McLendon C, Tucci M, Hamadain E, Benghuzzi H. Differential effects of cortisol on MRC-5 fibroblasts and hypertrophic LL-29 fibroblasts. Biomed Sci Instrum 2006; 42: 344-349.

25 Alam ZI, Jenner A, Daniel SE, Lees AJ, Cairns N, Marsden CD, Jenner P, Halliwell B. Oxidative DNA damage in the Parkinsonian brain: An apparent selective increase in 8-hydroxyguanine levels in substantia nigra. J Neurochem 1997; 69: 11961203.

26 Dexter DT, Carter CJ, Wells FR, Javoy-Agid F, Agid Y, Lees A, Jenner P, Marsden CD. Basal lipid peroxidation in substantia nigra is increased in Parkinson's disease. J. Neurochem 1989; 52: 381389.

27 Cheng YF, Zhu GQ, Wang M, Cheng H, Zhou A, Wang N, Fang N, Wang XC, Xiao XQ, Chen ZW, Li QL. Involvement of ubiquitin proteasome sys- tem in protective mechanisms of Puerarin to MPP(+)-elicited apoptosis. Neurosci Res 2009; 63: 52-58.

28 Xie HR, Hu LS, Li GY. SH-SY5Y human neuroblastoma cell line: in vitro cell model of dopaminergic neurons in Parkinson's disease. Chin Med J (Engl) 2010; 123: 1086-1092.

29 Johnston HJ, Hutchison GR, Christensen FM, Peters S, Hankin S, Stone V. Identification of the mechanisms that drive the toxicity of $\mathrm{TiO}_{2}$ particulates: the contribution of physicochemical characteristics. Part Fibre Toxicol 2009; 6: 33.

30 Grassian VH, O'shaughnessy PT, AdamcakovaDodd A, Pettibone JM, Thorne PS Inhalation exposure study of titanium dioxide nanoparticles with a primary particle size of 2 to $5 \mathrm{~nm}$. Environ Health Perspect 2007; 115: 397-402.

31 Stone V, Shaw J, Brown DM, Macnee W, Faux SP, Donaldson K. The role of oxidative stress in the prolonged inhibitory effect of ultrafine carbon black on epithelial cell function. Toxicol In Vitro 1998; 12: 649-659.

32 Araujo L, Lobenberg R, Kreuter J. Influence of the surfactant con-centration on the body distribution of nanoparticles. J Drug Target 1999; 6: 373-385.

33 Allouni ZE, Cimpan MR, Hol PJ, Skodvin T, Gjerdet NR. Agglomeration and sedimentation of $\mathrm{TiO}_{2}$ nanoparticles in cell culture medium. Colloids Surf B Biointerfaces 2009; 68: 83-87.

34 Ji Z, Jin X, George S, Xia T, Meng H, Wang X, Suarez E, Zhang H, Hoek EM, Godwin H, Nel AE, Zink JI. Dispersion and stability optimization of $\mathrm{TiO}_{2}$ nanoparticles in cell culture media. Environ Sci Technol 2010; 44: 7309-7314.

35 Oda T, Iwaoka J, Komatsu N, Muramatsu T. Involvement of $\mathrm{N}$-acetylcysteine-sensitive pathways in ricin-induced apoptotic cell death in U937 cells. Biosci Biotechnol Biochem 1999; 63: 341348.

36 Danfour M, Schorah CJ, Evans SW. Changes in sensitivity of a human myeloid cell line (U937) to metal toxicity after glutathione depletion. Immunopharmacol Immunotoxicol. 1999; 21: 277293.

37 Janssen YM, Marsh JP, Driscoll KE, Borm PJ, Oberdörster G, Mossman BT. Increased expression of manganese-containing superoxide dismutase in rat lungs after inhalation of inflammatory and fibrogenic minerals. Free Radic Biol Med 1994; 16: 315-322.

38 Sarsour EH, Venkataraman S, Kalen AL, Oberley LW, Goswami PC. Manganese superoxide dismutase activity regulates transitions between quiescent and proliferative growth. Aging Cell 2008; 7: 405-417. 
39 Aruoma OI, Halliwell B, Hoey BM, Butler J. The antioxidant action of $\mathrm{N}$-acetylcysteine: its reaction with hydrogen peroxide, hydroxyl radical, superoxide, and hypochlorous acid. Free Radic Biol Med 1989; 6: 593-597.

40 Menon SG, Sarsour EH, Kalen AL, Venkataraman S, Hitchler MJ, Domann FE, Oberley LW, Goswami PC. Superoxide signaling mediates Nacetyl-L-cysteine-induced G1 arrest: regulatory role of cyclin D1 and manganese superoxide dismutase. Cancer Res 2007; 67: 6392-6399.

41 Menon SG, Sarsour EH, Spitz DR, Higashikubo R, Sturm M, Zhang H, Goswami PC. Redox regulation of the $\mathrm{G} 1$ to $\mathrm{S}$ phase transition in the mouse embryo fibroblast cell cycle. Cancer Res 2003; 63: 2109-2117.

42 Ueno T, Yamada M, Igarashi Y, Ogawa T. N-acetyl cysteine protects osteoblastic function from oxidative stress. J Biomed Mater Res A 2011; 99: 523 531.

43 Townsend DM, Tew KD, Tapiero H. The importance of glutathione in human disease. Biomed Pharmacother 2003; 57: 145-155.

44 Sims NR, Nilsson M, Muyderman H. Mitochondrial glutathione: A modulator of brain cell death. J Bioenerg Biomembr 2004; 36: 329333.

45 Muyderman H, Nilsson M, Sims NR. Highly selective and prolonged depletion of mitochondrial glutathione in astrocytes markedly increases sensitivity to peroxynitrite. J Neurosci 2004; 24: 8019 8028.

$46 \mathrm{Wu}$ J, Sun J, Xue Y. Involvement of JNK and P53 activation in G2/M cell cycle arrest and apoptosis induced by titanium dioxide nanoparticles in neuron cells. Toxicol Lett 2010; 199: 269-276.
47 Zafarullah M, Li WQ, Sylvester J, Ahmad M. Molecular mechanisms of $\mathrm{N}$-acetylcysteine actions. Cell Mol Life Sci 2003; 60: 6-20.

48 Walther UI, Stets R. Glucocorticoid pretreatment increases toxicity due to peroxides in alveolar epithelial-like cell lines. Toxicology 2009; 256: 4852.

49 Mutsaers HA, Tofighi R. Dexamethasone Enhances Oxidative Stress-Induced Cell Death in Murine Neural Stem Cells. Neurotox Res 2012; 22: 127-137.

50 Fukawa E, Tanaka H, Makino Y, Hirano F, Akama H, Kawai S, Makino I. Homologous down-regulation of the glucocorticoid receptor down-modulates cellular hormone responsiveness in human histiocytic lymphoma U937 cells. Endocr J 1994; 41: 623-630.

51 Oakley RH, Cidlowski JA. Homologous down regulation of the glucocorticoid receptor: the molecular machinery. Crit Rev Eukaryot Gene Expr 1993; 3: 63-88.

52 Murr C, Fuith LC, Widner B, Wirleitner B, BaierBitterlich G, Fuchs D. Increased neopterin concentrations in patients with cancer: indicator of oxidative stress? Anticancer Res 1999; 19: 1721-1728.

53 Zhang L, Bai R, Li B, Ge C, Du J, Liu Y, Le Guyader L, Zhao Y, Wu Y, He S, Ma Y, Chen C. Rutile $\mathrm{TiO}_{2}$ particles exert size and surface coating dependent retention and lesions on the murine brain. Toxicol Lett 2011; 207: 73-81.

54 Speth C, Stöckl G, Fuchs D, Wirleitner B, Widner B, Würzner R, Mohsenipour I, Lass-Flörl C, Dierich MP. Inflammation marker 7,8-dihydroneopterin induces apoptosis of neurons and glial cells: a potential contribution to neurodegenerative processes. Immunobiology 2000; 202: 460-476. 